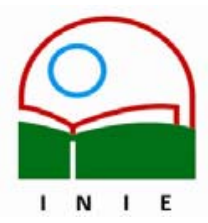

Universidad de Costa Rica

Facultad de Educación

Instituto de Investigación en Educación

ACTUALIDADES INVESTIGATIVAS EN EDUCACION

\title{
CONTENT-BASED INSTRUCTION IN AN ENGLISH ORAL COMMUNICATION COURSE AT THE UNIVERSITY OF COSTA RICA
}

\author{
Annabelle Hernández Herrero ${ }^{1}$
}

\begin{abstract}
This article presents the results of a research study carried out with a group of second-year English students at the School of Modern Languages at the University of Costa Rica. The purpose of this investigation was a) to find out if the recycling of content through the use of a variety of authentic informational sources (readings, videos, brochures, newspapers, movies, lectures, etc.) contributes to the improvement of the students' oral production skills, b) to identify which tasks best promote the oral participation of the students, c) to determine how to integrate the teaching of pronunciation into everyday classroom activities and d) to determine which linguistic aspects have to be reinforced to improve the students' accuracy and fluency in oral production tasks.
\end{abstract}

Key words: CONTENT-BASED INSTRUCTION (CBI)/ AUTHENTIC SOURCES/ ORAL PRODUCTION SKILLS/ TASKS/ IMPROVE/

Resumen: El propósito de este artículo es reportar los resultados de un estudio que se llevó a cabo con un grupo de estudiantes de inglés de segundo año de esta carrera en la Escuela de Lenguas Modernas de la Universidad de Costa Rica. Se investigó si la producción oral de los estudiantes mejora con el uso de contenidos auténticos provenientes de diferentes fuentes (lecturas, vídeos, panfletos, periódicos, conferencias u otros) que sirven como punto de partida (input) para las diferentes actividades de clase. Además se investigó cuáles actividades promueven mejor la participación oral de los estudiantes, cómo integrar mejor la enseñanza de la pronunciación dentro de las actividades del curso y cuáles aspectos lingüísticos se deben reforzar con el fin de mejorar la fluidez y precisión de los estudiantes en la producción oral del material estudiado en clase.

Palabras clave: INSTRUCCIÓN BASADA EN CONTENIDOS (CBI)/ FUENTES AUTÉNTICAS/ HABILIDADES DE PRODUCCIÓN ORAL/TAREAS/ MEJORAR/

\section{Introduction}

The School of Modern Languages of the University of Costa Rica offers a Bachelor of Arts Degree in English and a Bachelor of Arts Degree in the Teaching of English as a Foreign Language, the latter offered in conjunction with the School of Education. LM-1230 - Oral Communication I - is a second-year course for both majors. The main goal of this course is to improve the students' oral communication skills. In addition, the students learn to use the

\footnotetext{
1 Magíster en la Enseñanza del Inglés como Lengua Extranjera, Licenciada en Lengua Inglesa ambos títulos de la Universidad de Costa Rica. Ha impartido cursos de inglés como lengua extranjera en la Escuela de Lenguas Modernas y cursos de metodología y práctica docente en la Facultad de Educación y en la Escuela de Lenguas Modernas de la Universidad de Costa Rica. Ha publicado en el área de metodología y sociolingüística y es coautora del libro Understanding What I Read de la Universidad Estatal a Distancia
}

Correo electrónico: ahanglada@hotmail.com

Artículo recibido: 11 de octubre, 2005

Aprobado: 21 de noviembre, 2005 
phonetic alphabet with an emphasis on vowel sounds. The LM-1230 students, however, very often complain that they do not really have the opportunity to continue making progress because most of the class time is spent listening to classmates give speeches and oral reports instead of using the language in real communication situations.

According to Stryker and Leaver (1997) language learning has been compared to learning to ride a bike or learning to play an instrument. Even though it is widely recognized that the best way to learn these skills is by doing them, and not by just studying them or performing exercises and drills, traditional foreign language classes resemble a music class in which the students spend time practicing scales and theory instead of playing real pieces (p.1). This is what very often happens in the oral communication courses. The students prepare a speech, they present it to the class, and the professor and classmates give them feedback. Teachers also comment that these oral reports are memorized and, therefore, do not really show what the students are able to do with the language. These classroom experiences do not resemble what students will have to do with language in real-life contexts either. Furthermore, what the students do in class is not often in accordance with the course objectives.

It is widely recognized by teachers that language is most effectively learned in context. Regardless of the methodology used, teachers agree that contextualization of language items is a characteristic of good language classes; however, the controversy has centered around the role content should play in language teaching, and how content can best be integrated into the language classroom. Some methodologists claim that contextualizing language lessons is not enough. They suggest authentic written and oral texts -- texts which are not created for language teaching purposes -- as a starting point of every lesson. These texts provide samples of the structures, functions, and discourse features that native speakers use. Teachers can then focus on particular language forms and functions found in those readings in order not to leave aside the linguistic aspect of language learning. (Brinton et al., 1989 pp.1-2) This is what content-based instruction is about. Content-based foreign language instruction $(\mathrm{CBI})$ encourages students to learn a language by actually using the language as a real means of communication. How is this achieved? "By shifting the focus of instruction from the learning of language per se to the learning of language through the study of subject matter" (Stryker and Leaver, 1997, p. 5). Experience in foreign language classrooms has shown that $\mathrm{CBI}$ approaches have "the potential to enhance students' motivation, to accelerate students' acquisition of language proficiency, to broaden cross-cultural knowledge, and to 
make the language learning experience more enjoyable and fulfilling." (Stryker and Leaver, 1997, p. 5)

The professors teaching LM-1230 - Oral Communication I during the first semester of 2004 decided to implement $\mathrm{CBI}$ in order to achieve the course's main objective: to develop the students' oral communication skills. We reworded the objectives in order to fit the new methodology. Thus our general goal was to improve the students' oral communication and study skills through exposure to content from a variety of informational sources. In addition, the students learned to use the phonetic alphabet as a tool to improve their pronunciation. The specific objectives were 1) to accelerate the students' growth in oral proficiency, 2) to show understanding of the topics studied in class 3 ) to use appropriate language and pronunciation, intonation and stress when talking about the topics assigned 4) to use different conversation management strategies and 5) to develop critical thinking skills.

This article presents the results of a research study carried out with a group of secondyear English students at the University of Costa Rica. The purpose of this investigation was to find out if $\mathrm{CBI}$ was effective in achieving the course objectives.

\section{Theoretical Framework}

Content-Based Instruction ( $\mathrm{CBI}$ ) refers to an approach to second/foreign language teaching in which teaching is organized around content or information rather than around forms, functions, situations or skills. According to Chamot and O'Malley

There are at least four reasons for incorporating content into the English as a Second Language (ESL) class. First, content provides students with an opportunity to develop important knowledge in different subject areas. (....)

Second, students are able to practice the language functions and skills needed to understand, discuss, read about, and write about the concepts developed. A third reason .... is that many students exhibit greater motivation when they are learning content than when they are learning language only. Finally, content provides a context for teaching students learning strategies..... (1994, p. 26)

This focus on content knowledge, however, does not require a sacrifice of linguistic skills. On the contrary, $\mathrm{CBI}$ implies a dual commitment to language and content-learning objectives. According to Stoller (2004), in some settings, teachers focus more on language; in others, they focus more on the subject matter. 
Krahnke offers the following definition of $\mathrm{CBI}$ :

It is the teaching of content or information in the language being learned with little or no direct or explicit effort to teach the language itself separately from the content being taught. (Krahnke 1987, in Richards and Rodgers 2001, p. 204)

According to Stryker and Leaver (1997), CBI is more a philosophy than a methodology; therefore, there is no single formula for its implementation. Some of the most common models used worldwide include sheltered content courses, adjunct courses, theme-based and area studies modules, Language for Special Purposes (LSP), Collaborative Strategic Reading (CSR), Concept-Oriented Reading Instruction (CORI), and foreign languages across the curriculum (FLAC) (p. 3).

Regardless of the model, in order to successfully implement a CBI curriculum, the following characteristics must be present: 1) a subject-matter core, 2) authentic language and texts, and 3) content and learning activities appropriate to the needs of specific groups of students.

\section{Subject Matter Core}

All CBI models

....share the fact that content is the point of departure or organizing principle of the course - a feature that grows out of the common underlying assumption that successful language learning occurs when students are presented with target language materials in a meaningful, contextualized form with the primary focus on acquiring information. (Brinton et al., Wesche, 1989, p. 17 in Nunan 2001, p. 209)

This assumption is backed by a number of studies (e.g., Scott, 1974; Collier, 1989; Grandin, 1993; Wesche, 1993, in Nunan 2001) that support the position that in formal educational settings, second languages are best learned when the focus is on mastery of content rather than on mastery of language per se (p. 209).

\section{Use of authentic language and texts}

Another aspect of content-based approaches is the use of authentic language and texts. The learning activities should focus on understanding and conveying meaningful messages and accomplishing realistic tasks using authentic language. 
The content can be fun, academic, local, or school-based. It may include texts, videotapes, audio recordings, mini-lectures, field trips, community resources, student knowledge, web resources and visual aids (posters, maps, bulletin boards) selected mostly from those produced for native speakers of the language (Stoller 2004, Stryker and Leaver (1997, p. 8). Due to this fact, teachers will very often be working with materials which are beyond the current proficiency level of the students. It is important, therefore, for teachers to be skillful enough to use the texts in such a way that most students can benefit from authentic materials regardless of their level of proficiency. Bernhardt (1986, in Stryker and Leaver, 1997) suggests replacing the idea of "graded texts" by "graded activities." In order to make texts accessible to the students' proficiency level, teachers should know how to grade activities and how to use a wide variety of teaching strategies. In addition, when selecting the content, teachers should look for familiar topics for which students already possess the linguistic, content, and cultural background knowledge (p. 5).

\section{Appropriate to the needs of specific students}

In addition, in $\mathrm{CBI}$ approaches the content and learning activities correspond to the linguistic, cognitive, and affective needs of the students and are appropriate to their professional needs and personal interests. Even though course designers sometimes have to make initial guesses concerning the topics and materials which will be more appropriate for a particular group of students, teachers must be flexible enough to make the necessary adjustments based on an ongoing assessment of student outcomes. Since students have different learning styles, teachers should provide a variety of task types, develop a wide range of learning strategies, and use different grouping techniques to make the materials accessible to all the students in the classroom. Students should also be given participation in choosing topics and activities to better meet their needs and interests. "Student-generated themes and activities create an atmosphere in which the students take responsibility for their own learning and the teacher becomes more of a "manager of student learning" (Maly, 1993, p. 41 in Stryker and Leaver, 1997, p. 11)

According to Stoller (2004) the following eight principles should be taken into consideration when designing a $\mathrm{CBI}$ course:

Principle 1 - Use of sustained input, meaningful output, and feedback

This means that the topic should extend beyond one single class period, students should engage in speaking and writing activities, and feedback should focus on language and content as well. 


\section{Principle 2 - Student engagement in information gathering, processing, and reporting}

In a typical academic cycle, the students will gather information, process it, and report the results. For example, students might summarize the information, design a poster or a school flyer, and share it with other classes.

\section{Principle 3 - Integration of language skills}

$\mathrm{CBI}$ views language use as involving several skills together. In a content-based class, students are often involved in activities that link the skills, as generally happens in the real world. For example, students might read and take notes or write a summary. They might also respond orally to things they have read or listened to.

Principle 4 - Training of students to use strategies that will assist them in content and language learning

Instructors must teach strategies in authentic tasks and train the students to use a variety of strategies.

\section{Principle 5-Use of visual support to promote language and content learning}

A characteristic of $\mathrm{CBI}$ is the use of visual support such as graphic organizers, pictures, and realia. Graphic organizers can help students understand, summarize and remember information when reporting their work in speaking activities and jigsaw presentations; pictures and realia can illustrate topic-relate vocabulary.

\section{Principle 6 - Contextualization of grammar instruction}

In $\mathrm{CBI}$, grammar is not viewed as a separate dimension of language. It is seen as a component of other skills. Grammar should emerge from sources. It should be a direct outgrowth of input, output, and curricular objectives. The grammar we teach should help the students access information and talk about it. The instructor or course developer has the responsibility to identify relevant grammatical and other linguistic focuses to complement the topic or theme of the activities.

\section{Principle 7 - Development of task complexity and challenge}

Instructors should design tasks that require students to reinvest language skills, cognitive skills, and content knowledge. They should give students opportunities for problem solving. In addition, they should model, coach and scaffold activities. 


\section{Principle 8-Development of curricular coherence}

Course developers should look for ways to hold themes or topics together and look for a cohesive set of topics. They should avoid a mismatch or mixture of topics.

To summarize, we can say that there are some basic principles that teachers should follow in order to successfully use CBI. However, there is no single formula for its implementation; therefore, teachers are free to select the model which is more appropriate to their context and to choose content and activities which correspond to the linguistic, cognitive and affective needs of particular groups of students. An ongoing evaluation of the course will dictate the changes necessary to adapt to situations which are difficult to predict before the course begins.

\section{The Study}

\subsection{General Objective}

To determine if the use of authentic content from a variety of sources (readings, videos, pamphlets, newspapers, lectures) as a point of departure (input) for different classroom tasks improves the students' oral production skills.

\subsection{Specific Objectives}

3.2.1 To determine if the recycling of content through the use of a variety of sources contributes to the improvement of the students' oral production skills

3.2.2 To identify which tasks best promote the oral participation of the students

3.2.3 To determine how to integrate the teaching of pronunciation into everyday classroom activities

3.2.4 To determine which linguistic aspects should be reinforced to improve the students' accuracy and fluency in oral production tasks

\subsection{Participants}

A total of 21 LM-1230 - Oral Communication I students, 7 men and 14 women, studying English at the University of Costa Rica during the second semester of 2004, participated in the study. The students whose age ranged from 19 to 52 were all native speakers of Spanish. They met from 7:00 a.m. to 8:50 a.m. on Mondays and Wednesdays, and on Fridays, they attended a lab session from 7:00 a.m. to 8:50 a.m. 


\subsection{Faculty and Materials}

A major component in the implementation of $\mathrm{CBI}$ is the instructors' willingness to devote the time and effort required to look for a variety of resources and materials such as readings, videos, lecturers, and their willingness to design/adapt tasks to accompany those materials. This is a huge task that requires the collaboration of all the faculty members involved in the design and implementation of the course. Furthermore, since the professors teaching the $\mathrm{CBI}$ course are not experts in the subject matter, they have to take time to acquire the knowledge and special skills required to be competent to teach and to train students in the specific topic(s). Four instructors accepted this challenge and worked actively throughout the first semester of 2004 to successfully achieve the goals. Based on the results of this first experience with $\mathrm{CBI}$, some changes were made during the second semester when the investigation took place. This time another professor also collaborated with materials, comments, and suggestions.

\subsection{The Data}

The following instruments were used to gather information:

(a) Students' evaluations of the readings and activities carried out in class, (b) Teachers' evaluations of readings and activities carried out in class, (c) The scores of the proficiency assessment and two oral exams. For the purpose of this project, when the comments in the evaluations of teachers and students were in English, I transcribed them verbatim. When they were in Spanish, I translated them.

\subsubsection{Students' Evaluations of Texts and Activities}

The researcher piloted and evaluated the texts and the oral activities specifically designed for this project through questionnaires and interviews during the first semester of 2004. Some texts were eliminated and others added based on the results of this evaluation.

\subsubsection{Three oral exams}

\section{Proficiency Assessment}

The students were asked to prepare a 5-10 minute oral report on a topic of their choice to present to the class. These reports were presented three per class in order to carry out other course activities and to give variety to the lessons. They were graded by the course instructor with the same evaluation scale that was used in the first and second exams. 


\section{Two exams}

The first exam took place after the first module was finished. The students were evaluated in pairs by two course instructors. The exam consisted of two parts: one topicrelated situation to be developed in pairs and one question for each participant. For the second part, Student A asked B a question and vice versa; however, the student asking the question had to participate actively, asking for clarification or repetition, adding comments or complementing his/her partner's answers (See Appendix B for sample questions and situations). The second exam took place at the end of the semester and evaluated the other module. The same procedure was followed to administer and grade this exam.

\subsection{Methodology}

As mentioned before, the general objective of LM-1230, Oral Communication I, is to improve the students' oral communication and study skills through exposure to content from a variety of informational sources, and to learn to use the phonetic alphabet as a pronunciation tool emphasizing the vowel sounds.

Our first task was to select the content to be studied during the semester. Since the materials for at least the first module had to be ready before the beginning of the course, we based our selection of topics on comments by teachers who had taught this course before. They suggested topics of oral reports that had interested the students the most. In order to give the entire course some unity, we organized it around one major theme which was then further subdivided into more specialized topics. We chose responsibility as our unifying element and created two self-contained modules -- environmental issues and drug abuse -which were independent of one another and could be used in any sequence, but, as mentioned above, were linked to each other by a central theme. The language items to be taught were not selected in advance. The content and the students' needs throughout the semester dictated their selection and sequence. Based on the students' evaluations, in the second semester, we broadened the second module to include other types of addictions. Also, for the group project, we let the students investigate a topic of their choice. These changes gave more variety to the course and took into account students' preferences.

Because we wanted to emphasize oral skills, we did not rely on written input only. We included videos, a movie, lectures and any other kinds of materials which served to reinforce and recycle the topics to be studied during the semester. In addition, the written texts were recorded by native speakers. In this way, the students could read and listen to them before 
the oral activities took place. We also tested different oral communication tasks to determine which would encourage the students to talk as much as possible.

If students were not going to spend most of the class time giving oral reports in front of the class, it was necessary to look for another way to evaluate them and give them individual feedback. I decided to sit with a group every time they had team presentations and give that particular group of students a grade and feedback on their individual performance. The other groups' oral presentations were peer evaluated. The students were also graded after the performance of the oral task through a written quiz or a group report based on all the information.

In order to give continuity to all the oral communication classes, the professors decided to use the same pronunciation book in all the oral courses. We selected the book Focus on Pronunciation, and in Oral Communication I, we focused on the eleven American vowels. We also used the video "Vowels and Diphthongs" to complement the units.

\section{Analysis and Results}

\subsection{To determine if the recycling of content through the use of a variety of sources contributes to the improvement of the students' oral production skills}

Twenty-one students took the three tests. A T-test for dependent samples was run. The probability value associated with a $\partial=5 \%$ (reliability level of $95 \%$ ) was compared. The following hypotheses were tested:

Ho: The percentage of students who got grades higher than 8 in the first test, classified as very good or good, remain in this category in subsequent tests.

Ha: The percentage of students who got grades higher than 8 in the first test, classified as very good or good, do not remain in this category in subsequent tests. 


\section{CROSS TABLES}

\section{Table 1}

Comparison between initial test and first recorded test

\begin{tabular}{|c|c|c|c|c|c|c|c|}
\hline & & \multicolumn{4}{|c|}{ First recoded test } & & \\
\hline & & \multicolumn{2}{|c|}{ Fair - Poor } & \multicolumn{2}{|c|}{$\begin{array}{c}\text { Very } \\
\text { Good-Good }\end{array}$} & \multicolumn{2}{|c|}{ Total } \\
\hline & & $\mathrm{N}$ & $\%$ & $\mathrm{~N}$ & $\%$ & $\mathrm{~N}$ & $\%$ \\
\hline \multirow[t]{2}{*}{ Initial test } & Fair-poor & 7 & 77.8 & 5 & 41.7 & 12 & 57.1 \\
\hline & Very good-Good & 2 & 22.2 & 7 & 58.3 & 9 & 42.9 \\
\hline Total & & 9 & 100.0 & 12 & 100.0 & 21 & 100.0 \\
\hline
\end{tabular}

Table 2

Comparison between initial test and second recorded test

\begin{tabular}{llrrrrrr}
\hline \hline & & \multicolumn{3}{c}{ Second recorded test } & & \\
\cline { 3 - 6 } & & \multicolumn{2}{c}{ Fair-Poor } & \multicolumn{2}{c}{ Very good-Good } & & \multicolumn{2}{c}{ Total } \\
\cline { 3 - 6 } & & $\mathrm{N}$ & \multicolumn{1}{c}{$\%$} & $\mathrm{~N}$ & $\%$ & $\mathrm{~N}$ & $\%$ \\
\hline Initial test & Fair-Poor & 10 & 90.9 & 2 & 20.0 & 12 & 57.1 \\
& Very good-Good & 1 & 9.1 & 8 & 80.0 & 9 & 42.9 \\
Total & 11 & 100.0 & 10 & 100.0 & 21 & 100.0 \\
\hline \hline
\end{tabular}

Table 3

Comparison between the first recorded test and the second recorded test

\begin{tabular}{llrrrrrr}
\hline \hline & & \multicolumn{3}{c}{ Second recorded test } & \multicolumn{2}{c}{ Total } \\
\cline { 3 - 6 } & & \multicolumn{2}{c}{ Fair-Poor } & \multicolumn{2}{c}{ Very good-Good } & \multicolumn{2}{c}{} \\
\cline { 3 - 7 } & & $\mathrm{N}$ & $\%$ & $\mathrm{~N}$ & $\%$ & $\mathrm{~N}$ & $\%$ \\
\hline First recorded & Fair-Poor & 5 & 45.5 & 4 & 40.0 & 9 & 42.9 \\
test & Very good-Good & 6 & 54.5 & 6 & 60.0 & 12 & 57.1 \\
Total & & 11 & 100.0 & 10 & 100.0 & 21 & 100.0 \\
\hline \hline
\end{tabular}




\section{McNemar Tests}

Test Statistics ${ }^{b}$

\begin{tabular}{lrr}
\hline \hline & $\mathrm{N}$ & $\begin{array}{r}\text { Exact Sig. } \\
\text { (2-tailed) }\end{array}$ \\
\hline Initial test versus First recorded test & 21 & $.453^{\mathrm{a}}$ \\
Initial text versus Second recorded test & 21 & $1.000^{\mathrm{a}}$ \\
First recorded test versus second recorded test & 21 & $.754^{\mathrm{a}}$ \\
\hline \hline
\end{tabular}

a. Binomial distribution used.

b. McNemar Test

Based on the results of the tests with a significance level of $5 \%$, we arrived at the following conclusions:

There is no evidence to reject the null hypothesis $(\mathrm{Ho})$; therefore, the percentage of students who got grades higher than 8 in the first test, classified as very good or good, remain in this category in subsequent tests.

Table 1 compares the proficiency assessment with Exam 1. We can observe that in the proficiency assessment, 12 students were categorized as fair or poor and 9 students as very good or good. If we compare the results of this initial assessment with the first exam, we can see that 7 students who were fair or poor remained in the same category, 2 who were very good or good changed to fair, 5 who were fair or poor moved to very good or good, and 7 who were good or very good remained in the same category.

Table 2 compares the proficiency assessment with Exam 2. We can observe that 10 students remained as fair or poor, one who was very good or good moved to poor or fair, 2 who were poor or fair changed to very good or good, and 8 who were very good or good remained in the same category.

Table 3 compares the results of Exam 1 and 2: 5 students who were poor or fair remained the same, 6 who did well or very well moved to the lower category, 4 who were poor or fair went up to a higher category, and 6 good or very good students continued the same way.

If we study the cross tables, we can observe that:

1. The majority of the students whose initial scores were categorized as poor or fair continued in the same category. I can also add that they encountered the most problems and received the lowest grades in the course.

2. Only a few students moved to a higher category throughout the semester. 
However, we must take into consideration that for the proficiency assessment, the students had the opportunity to select the topic and prepare an oral presentation. They could also bring different visual aids to help them convey meaning. For exams 1 and 2, even though the subject matter was studied in class, and the students were given situations and questions to get ready for the exam, their performance was much more spontaneous since the tasks were selected at random, and it was impossible for the students to memorize all of them.

In my opinion, and based on careful observation of the students' results in performance of tasks and exams, it seems that the students need a solid language background to get full advantage of $\mathrm{CBI}$. Many times they know the subject matter, but their language limitations do not allow them to perform well. Since most of the time content-based tasks are given more importance and take more class time than grammar-based tasks, low-level students are unable to overcome those linguistic problems. Unless special attention is given to troublesome target structures, students will not be able to improve, and they will continue struggling with these problems in higher levels.

\subsection{To identify which tasks best promote the oral participation of the students}

The second objective of this study was to identify which tasks best promoted the oral participation of the students. The following resources, materials, and tasks were used with the pilot group the first semester of 2004: oral presentations in front of the class, jigsaw readings, group discussions, debates, pair work activities, a field trip, a variety of visual aids such as graphic organizers, charts, story maps, and illustrations, among others. Some of the tasks were used because they were course requirements, for example, the oral reports in front of the class. Cooperative learning tasks such as jigsaw activities were selected by the instructor because they allow for greater quantity and variety of language practice and improve the quality of student talk (Long \& Porter, 1985), and finally tasks such as the field trip, videos, and movies provided variety of informational sources, an important principle of CBI.

At the end of the first semester of 2004, the students were given a list of activities and were asked the questions: "Which of the following activities helped you improve your oral communication skills? Give reasons for your choice," "What other things helped you improve your oral communication skills?" The materials, resources and tasks for the second semester of 2004 were selected by the instructor based on the results of this evaluation. Here is a description of the most frequent tasks used in the lessons, and the comments the students made in their evaluations. 


\subsubsection{Oral Presentations in front of the class}

All the students gave two oral presentations in front of the class. In addition to the diagnostic assessment, the students, in groups of four, carried out an investigation project on a topic of their own choice. In the evaluations of the first semester of 2004, the students complained that they had gotten tired of the same subject matter and expressed their wish for more freedom of choice for their research projects. During the second semester, therefore, the professors teaching the course accepted this suggestion, even though it was not in accordance with the principles of $\mathrm{CBI}$. The students used their creativity to present the results of the investigation to the class and to check understanding. This gave variety to the lessons, although it did not add information or reinforce the topics studied in class.

These are some comments the students made about oral presentations:

- "First, oral presentations have the advantage that the students become less afraid to talk in front of the class, and second, the student has to prepare better because talking in front of an audience requires more preparation and better knowledge of the subject matter." (my translation)

- "I get too nervous and I forget the skills I'm supposed to know." (my translation)

- "The class is yours. You can move, see and have the attention of everyone. You can feel comfortable and loose."

- "You talk about a topic nobody knows about. You learn not to have stage fright. I like it." (my translation)

- "It gave me the opportunity to improve my oral skills by using the different tips the prof. and partners recommed me [sic.] $]^{2}$."

- "They are important and very useful, but at the same time the student gets very nervous and makes more mistakes than usual." (my translation)

- "It's better to work in circle [sic.] in my case I feel better instead to talk [sic] in front of the class."

Based on these comments and in order to pay more attention to individual learning styles, some students were given the opportunity to give additional oral presentations, especially on the topic of addictions.

To summarize, many students found oral presentations helpful to improve their oral production skills because they prepared their assignments more carefully; that is, they felt

\footnotetext{
${ }^{2}$ sic: Used within brackets to show that a quoted passage, esp. one containing an error, is reproduced accurately
} 
that facing the whole class required more of them than working in small groups. In addition, even though they felt nervous, oral presentations gave them the opportunity to practice public-speaking techniques, skills which are very important for students who plan to teach in the future.

\subsubsection{Jigsaw Readings}

Whenever possible, the readings and/or sub-topics were divided into self-contained sections for the students to master and present to their classmates in small, cooperative groups. The students in expert groups did reading comprehension exercises, prepared graphic organizers and/or visuals to illustrate the topic-related words or summarize ideas, and rehearsed their oral presentation before working in their jigsaw groups. The same procedure was also used with three real-life stories about drug abuse.

The professor evaluated the oral presentations and gave feedback to one group every time the technique was used. The rest of the groups were peer-evaluated, making use of an Oral Presentation Checklist. The instructor also administered a short quiz after the oral presentations based on all the information presented in the jigsaw groups.

The use of jigsaw reading substantially increased practice time since all the students participated simultaneously in the presentation of the topics. This ongoing evaluation, I believe, increased motivation to prepare assignments and improved attendance because the students knew they were given credit for their work in most of the classes. It also increased the students' responsibility to master their piece of information because their performance affected their teammates' learning and grades as well.

Here are some students' opinions about expert groups and jigsaw presentations:

- "Expert groups helped me to summarize the content of the readings better."

- "If I have doubts, my classmates or professor will clarify them." (my translation)

- "You organize better your ideas."

- "You can learn a lot about your classmates and you always adquire [sic] new vocabulary from them."

- "It [jigsaw presentations] also help me, because classmates talk to you and it's kind of intimate, so, you aren't feeling nervous because the whole class is staring at you."

- "...it's [jigsaw] good to learn to listen carefully."

- "...less stress, we complement each other, faster, more fun, we had to do it well, so all had the information." (my translation) 
To summarize, students thought that jigsaw activities were very helpful because they summarized the ideas in the readings, they learned new information and vocabulary from their classmates, and when they had doubts, teammates gave them explanations and helped them to clarify ideas. The students also felt more at ease and free to give opinions when working in small cooperative groups than when facing the whole class, so their individual oral participation increased substantially. However, some students expressed concern about classmates not giving them enough information or the correct information.

\subsubsection{Graphic Organizers}

The students prepared a variety of graphic organizers such as charts of various kinds, and semantic and story maps as aids to report their work in speaking activities or jigsaw presentations.

This is what students wrote:

- "I consider readings and graphic organizers very useful to increase my vocabulary and oral production skills because it is easier to learn the material when it is summarized."

- "I consider readings and graphic organizers very useful to increase my vocabulary and oral production skills because after we read we have to write the main ideas and organize and sequence them in order of importance."

Overall, students felt that graphic organizers were a great tool to understand the content, to summarize readings, to learn new vocabulary, and to recall information during oral productions tasks.

\subsubsection{Walk around, pair work activities}

Several walk around, pair work activities were used during the semester. I specifically evaluated one called Circulation. Half of the class was given a reading about marijuana and the other half one about alcoholism. The students in expert groups worked with their readings to master the information. The day the oral activity took place, the students who read about marijuana were given a handout with questions about alcoholism, and the students who read about alcoholism were given questions about marijuana. Each student was given a colorcoded number which corresponded to a question in the handout. They walked around the class looking for the right color-coded number and asked that person the corresponding question. 
After this information-sharing activity, all the students had thorough knowledge about both topics. The instructor asked individual students to write two paragraphs about the main points they learned on both topics. (Adapted from "It Works." Tesol Newsletter. XX (3), 18 by Janet Gainnotti)

This is what a student said about the task:

- "The activity we carried out in class today had advantages and disadvantages. I can mention the following advantages:

a) It is amazing how shyness diminishes when there isn't a professor listening to us and taking notes of what we say.

b) We are much more self-confident when we know our interlocutor is only one person.

c) The class is much more interactive. Nobody has time to fool around because we are all working at the same time.

In spite of the above, I have noticed the following disadvantages:

a) It is difficult to know if the assigned topic was well prepared by our classmates; that is, there is a possibility that a classmate is making up the information.

b) Since we depend on our classmates' answers to get the full idea of the topic, we do not master all the information assigned." (my translation)

On the whole, students thought that this was a very dynamic and useful activity to improve their oral production skills because they had to learn all the information and share it with their classmates, a very good way to test what they knew. Since they had to talk to only one person at a time, they felt very comfortable, and their fluency improved as the task progressed. In addition, they mentioned that they learned and had fun at the same time. Once again, they said that they practiced their English a lot and were not afraid to talk because they did not have to face the class. As in other group work activities, some students expressed concern about the veracity and the amount of information given by classmates.

\subsubsection{Debates}

The students were given information from a variety of sources about the issues to be debated, for example, "Should drugs be legalized?" "Smoking or nonsmoking?". They performed different tasks and had the opportunity to listen to the readings at home before the oral activity took place. I organized the debate in groups of 4 . First the students worked in pairs, one pair for and the other against the issue to be debated in order to come up with as 
many ideas as possible. When they were ready, they got in groups of four and the debate started. Students were encouraged to use the communication gambits appropriate for this type of discussion. The debate was followed by a wrap-up session with the whole class.

This is what some students said about debates:

- "You don't really prepare for a debate. It's spontaneous, so that measures your English level."

- "You have the opportunity to give your opinion without rehearsing." (my translation)

- "It is very exciting to debate about a topic. When you try to beat your opponent, your fluency is greatly improved." (my translation).

"Some talk more than others." (my translation)

\subsubsection{Group discussions}

The students were given questions about a topic to discuss in small groups. This type of activity was appropriate as a pre-reading task to find out how much the students knew about a topic, to introduce topic-related vocabulary, and to get the students interested in the topic. As a post-reading task, students had the opportunity to express their opinions about the topics studied or relate readings with our national context or their lives. In addition, they had a chance to use the language learned in different contexts and situations.

This is what some students said about this type of activity:

- "It is easier for us to talk with our classmate face to face than in front of the class."

- "Sometimes is not very usefull [sic.] to discuss in small groups because there's nobody to correct wrong pronunciation."

- "I learned a lot listen [sic.] to other classmates' opinions."

- "It is like debates, you can give your opinion and practice idioms (if you have the opportunity)."

- "The majority were opinion questions; therefore, there was more "freedom of speech" and we talked more than when it was a specific topic." (my translation)

To summarize, students thought that debates and group discussions gave them the opportunity to interact with classmates and practice English in spontaneous situations; therefore, they could assess how well they could perform in the target language. In addition, they learned to express opinions and defend a point. 


\subsubsection{Field Trip}

A field trip to EARTH University wrapped-up the first module. We wanted the students to: a) have the opportunity to complement and reinforce what they had learned in class by listening to and asking questions of an expert on the subject matter and b) observe the results of a successful waste management project and motivate them to apply at home and in their communities some of the knowledge acquired in this course.

Since the whole activity took place in English, the students had a chance to increase and reinforce their content knowledge and use their linguistic skills in a real-life situation. The benefits of an activity like this are clearly reflected in the comments made by the students:

- "The trip to Earth University was an excellent idea. It gave us the opportunity to be in direct contact with the topics studied in class. It was a great opportunity to expand the topic-related vocabulary. In addition, we practiced, applied and evaluated our general knowledge on the topic as well as our language skills. It is very exciting to experience in real life what we read in books." (my translation)

- "The most important thing I learned at Earth is that if each one of us follows some simple tips to classify, reuse and recycle garbage, the waste management problem we are facing these days wouldn't be so bad.....To visit a place where the culture of sustainability is practiced and to experience personally a successful waste management program can help us to reduce this problem. I could not write on one page all I learned, but now I know a landfill is not a dirty and dangerous place. I saw the difference between a landfill and a dump." (my translation)

All the students who visited EARTH University agreed that the field trip was a great activity to complement class work. It bridged the gap between theory and practice. They had the opportunity to experience in real life what they had read in books. In addition, they could also use their linguistic knowledge and assess their proficiency level in a real-life situation. Moreover, it was fun, it broke the routine, and they had a chance to share time with classmates and professors.

\subsubsection{Listening comprehension exercises and pronunciation drills}

The students did the drills and listening comprehension exercises included in the pronunciation textbook, worked with pop songs to practice recognition of vowel sounds and listened to topic-related conversations and lectures. They also watched the videos "From Waste to Wonderful," and "Nicotine" and saw the movie "Requiem for a Dream" to Volumen 5, Número 2, Año 2005, ISSN 1409-4703 
complement the first and second modules. The instructors prepared handouts with pre-, while- and post-viewing/listening exercises to accompany the videos, lectures, and the movie. The songs motivated the students and gave variety to the pronunciation lessons. The field trip, videos and movie added, reinforced, and exemplified information learned in readings and improved the students' listening comprehension and speaking skills.

When asked which activities helped them the most to improve their pronunciation, the students mentioned the following:

- Practicing in the lab

- Doing exercises in the phonetics book

- Transcribing words and repeating the transcribed words

- Looking up words in the dictionary

- Listening to words and repeating them over and over again

- Presenting oral reports

- Listening to cassettes and watching videos

- Working in group because you learn from partners

\subsubsection{Overall Evaluation of Activities by the Students}

Table 4 shows the students' ranking of the main tasks used in the second semester of 2004. The numbers represent the students who selected the tasks as first, second, etc. choice.

TABLE 4

\begin{tabular}{|l|c|c|c|c|c|c|c|}
\hline \multicolumn{1}{|c|}{ Tasks } & $\begin{array}{c}\text { First } \\
\text { Choice }\end{array}$ & $\begin{array}{c}\text { Second } \\
\text { choice }\end{array}$ & $\begin{array}{c}\text { Third } \\
\text { choice }\end{array}$ & $\begin{array}{c}\text { Fourth } \\
\text { choice }\end{array}$ & $\begin{array}{c}\text { Fifth } \\
\text { choice }\end{array}$ & $\begin{array}{c}\text { Sixth } \\
\text { choice }\end{array}$ & $\begin{array}{c}\text { Seventh } \\
\text { choice }\end{array}$ \\
\hline Oral Presentations & 6 & 2 & 0 & 3 & 2 & 1 & 5 \\
\hline Expert Groups & 2 & 6 & 4 & 2 & 1 & 4 & 0 \\
\hline Jigsaw Presentations & 4 & 4 & 4 & 4 & 1 & 1 & 1 \\
\hline Group Discussions & 3 & 5 & 3 & 5 & 1 & 1 & 1 \\
\hline Others & 1 & 1 & 4 & 2 & 5 & 3 & 3 \\
\hline Debates & 1 & 1 & 4 & 1 & 3 & 5 & 4 \\
\hline Circulation & 2 & 0 & 0 & 2 & 6 & 4 & 5 \\
\hline
\end{tabular}

Scale: First choice: the most helpful 
Based on Table I and the students' comments, we can conclude that oral presentations are found very important by a considerable number of students because they plan presentations more carefully if they know they have to face an audience. They also have the opportunity to practice simple public speaking techniques that will help them to improve their individual style of public speaking and to overcome stage fright. However, many students think that they feel more at ease and eager to participate when they work in pairs or in small cooperative groups. Group work tasks, such as jigsaw presentations and walk-around activities, are favored by the majority of the students. The benefits are greater if the students use visual aid such as graphic organizers, charts, and illustrations to help convey meaning and to recall information.

From a pedagogical point of view, variety is the key to success. Therefore, selecting different task types will keep the students interested and provide for individual differences and learning styles.

\subsection{To determine how to best integrate the teaching of pronunciation into every day classroom activities.}

The third objective of this study was to determine how to best integrate the teaching of pronunciation into every-day classroom activities. As was mentioned before, one of the main objectives of LM-1230 - Oral Communication I - is to learn to use the phonetic alphabet as a pronunciation tool emphasizing the eleven American vowel sounds. It has always been difficult, though, to integrate this element into the regular lessons and not to view pronunciation as a separate element in the course. The students have a lab class once a week, and it is mostly during this period that they do the pronunciation exercises. In order to integrate pronunciation practice into every day activities, I followed this procedure:

From the first day of the course, the International Phonetic Alphabet (IPA) was introduced, and the students practiced writing the symbols and transcribing simple words to become familiar with the alphabet. I gave the students individual feedback to make sure they were writing the symbols correctly.

Focus on Pronunciation dedicates a unit to each vowel sound and also compares and contrasts difficult sounds such as /// and /iy/. In the lab, I introduced the different units, and the students performed the exercises individually and in pairs. Once I went through the unit, I looked in the articles the students read for topic-related words with the sound(s) being studied, and we practiced those words. Students also were asked to transcribe the 
glossaries for homework. Since dictionaries use different symbols, we checked the words on the board and made sure the symbols they were using were the appropriate ones. In addition, before starting a new topic, the most important topic-related words were included in a glossary, and the students transcribed and learned the definition and pronunciation of the words before they worked in cooperative groups. If the list was long, I divided the words among the students, and the next day we wrote them on the board and practiced the pronunciation. In jigsaw presentations, debates and discussions, the students had a chance to recycle and to use the new words in context. During oral presentations and exams, I took note of the pronunciation errors including high-frequency words and topic-related word and followed the same procedure mentioned above.

To conclude, transcription and pronunciation practice of high-frequency words and topic-related words were part of every class the students had during the semester. These activities took place mostly before and after oral reports. The different oral tasks gave the students the opportunity to use in meaningful situations, sounds, words, and expressions that were previously drilled in isolation. Feedback and remedial tasks after oral presentations and exams provided additional practice and reinforcement of troublesome sounds and words.

This technique worked very well. The phonetic alphabet was really used as a tool to improve the students' oral production skills and not as a mere course requirement. Even though the focus of the pronunciation drills was on vowel sounds, the strategy used also helped the students improve their overall pronunciation.

\subsection{To determine which linguistic aspects should be reinforced to improve the students' accuracy and fluency in oral production tasks}

The fourth objective of this study was to determine which linguistic aspects had to be reinforced to improve the students' accuracy and fluency in oral production tasks. In this particular group of students, the following grammar points were troublesome for quite a number of students: subject-verb agreement, subject omission, indirect questions, another, other, others, overuse of the, prepositions, word choice, verb forms and tenses, among others. Here are some examples taken from the students' oral presentations and exams:

Subject-verb agreement: "You was saying ....," "My father smoke .....," "The people needs ....," "People is....," "This friend don't,"

Subject omission: "is very difficult to produce.", "is not recommended because is..." Indirect questions: "Do you know what is acid rain?" "....what kind of products do we have to buy in the future." 
Word order: "enough strong," "another part very important"

Overuse of the: "the deforestation contributes ....," "the Wednesday ....," "the AIDS ....,"

Verb forms and tenses: "....can be fight," "Can you came with me?"

Word choice: explications, examinated, do an effort, say me that

Prepositions: near to San Jose, arrive to, marry with, for to produce

Another, other, others: other problem, others problems, another ways

Some grammar-based activities were designed and implemented throughout the semester. As results of the study show, some students moved from the poor or fair category to the good or very good category; however, many of them were still not able to overcome their linguistic problems. It seems that with this particular group of students, more time should have been devoted to grammar-based activities rather than to subject matter tasks.

As a conclusion, although linguistic needs usually vary from group to group, there are certain grammar points that seem not to have yet been acquired by second-year students and need reinforcement. Although Krashen's "morphene order studies" have shown that formal instruction does not change the natural order of acquisition (Krashen, 1981, 1982, in Nunan, 1999), other research studies (Wudong Wu 1994 in Nunan 1999) have found that output activities that give the students the opportunity to activate target structures lead to their acquisition (p. 48). In a 1999 paper, Spada reviewed research studies on language acquisition carried out by herself and others in Canada (in Nunan, 1999), and she concluded that classrooms that were communicative in orientation but which provided opportunities for explicit grammatical instruction were superior to both traditional classroom activities that focused heavily on grammar, and to immersion programs that avoided explicit grammatical instruction (p. 47). Therefore, based on the results of these research studies, I suggest that instructors throughout the course become aware of the linguistic needs of their specific groups of students and a) design consciousness-raising activities which focus on form, meaning and use b) design topic-related tasks which activate target structures and c) train students to use strategies to help them overcome their linguistic problems. The time we devote to grammar-based activities or content-based tasks will depend on the needs of a particular group of learners.

\section{Implications}

1. Groups change every semester, and their language needs and learning styles might be different, too. A specific course program using $\mathrm{CBI}$ should be flexible enough to adapt 
it, if necessary, to fit the students' needs and to provide for individual and group differences.

2. $\mathrm{CBI}$ is not the answer to every problem in language instruction. If grammatical and other linguistic elements are left aside, the students' fluency might improve, but their comprehensibility will be greatly affected because of their lack of accuracy.

3. Teachers need to assess the group's language proficiency level at the beginning of the semester. If results show that the majority of the students' linguistic performance is low, teachers must give enough attention to language to help the students overcome their problems.

4. Teachers should allow the students to select the topic of their presentations and research projects, but limit their choice to the topics assigned in that particular course, for example, environmental and health issues in Oral Communication I. In this way, we will please the students, follow $\mathrm{CBI}$ principles, and give the course unity of content.

\section{Recommendations for further research}

1. Evaluate different communicative grammar-based activities to determine which ones help the students improve their accuracy in oral production activities.

2. Assess how to best integrate the teaching of grammar and other linguistic elements into every-day classroom activities.

3. Design a proficiency assessment which would yield more valid results to be compared with the other two exams.

4. Replicate the study with a group of higher language proficiency students to determine if $\mathrm{CBI}$ yields better results with students who possess a solid language background.

\section{References}

Brinton, D., et al. (1989). Content-Based Second Language Instruction. Boston: Heinle \& Heinle Publishers.

Brinton, D. and C. Holten. (1997). Into, Through, and Beyond: A Framework to Develop Content-Based Material. English Teaching Forum XXXV(4): 10-21.

Long, M. and P. Porter. (1985). Group Work, Interlanguage Talk, and Second Language Acquisition. Tesol Quarterly. 19(2): 207-225.

Nunan, D. (1999). Second Language Teaching \& Learning. Boston: Heinle \& Heinle Publishers. 
Richards, J. and T. Rodgers. (2001). Content-Based Instruction. In Approaches and Methods in Language Teaching. Cambridge: Cambridge University Press.

Stoller, F. (2004). Content-Based Instruction: Perspectives on Curriculum Planning. Annual Review of Applied Linguistics. 24, 261-283. U.S.A: Cambridge University Press.

Stoller, F. (2004). Principles to Guide in Integrating Content- and Language-Learning Objectives. XX National Conference for Teachers of English. San José, Costa Rica.

Stoller, F. (1997). Project Work: A Means to Promote Language Content. English

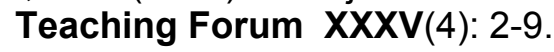

Stryker, S. and B. Leaver, Editors. (1997). Content-Based Instruction in Foreign Language Education: Models and Methods. Washington, D.C.: Georgetown University Press. 


\section{Appendixes}

\section{Appendix A}

Resources and Materials for LM-1230 - Oral Communication I

A. Reading materials:

1. Air Pollution (by Susan Stempleski)

http://exchanges.state.gov/forum/journal

2. What you can do to reduce pollution

3. Recycling and Reusing (by Susan Stempleski)

http://exchanges.state.gov/forum/journal

4. Commonly Recycled materials

"Water Pollution," Microsoft Encarta Online Encyclopedia 2004

http://encarta.msn.com c 1997-2004 Microsoft Corporation

5. Waste Management (by Susan Stempleski)

http://exchanges.state.gov/forum/journal

6. "Saving the Biramichi River" in Coelho, Elizabeth, Lise Winer, and Judy Winn-Bell, Olsen. 1989. All Sides of the Issue. California: Alemany Press

7. "Hero of the Hood," "For you, Dad," and "Firmer Ground" in Canfield, Jack and others. 1998. Chicken Soup for the Teenage Soul II. Deerfield Beach: Health Communications Inc.

8. Drug Addiction and Drug Abuse

9. FAQ's on Alcohol Abuse and Alcoholism

NIAAA WebMaster (niaaaweb-r@exchange.nih.gov

10. Marijuana Facts for Teens

http://www.teen-drugabuse.org do-you-know.htm

11. Hashish

http://I-cias.com/e.o/hashish.htm

12. LSD

http://www.drugabuse.gov/Infofax/lsd.html

13. Cocaine

14. Amphetamines

http://www.amphetamines.com/ice.html

15. Analgesics

16. Tranquilizers 
17. Barbiturates

http://www.recovery.org.uk/druginfo/index.html

18. Secondhand Smoke: The Real Risk for You and Your Family

Hilts, Philip J. 1996. Good Housekeeping.

B. Recordings of reading materials - all the readings were recorded by native speakers

C. Communication gambits

D. Videos:

From Waste to Wonderful - Recycling the EM Bokashi Way

Nicotine

The Video Encyclopedia of Drug Abuse

Vowels and Diphthongs

E. Field Trip

A visit to EARTH University

F. Commercial film:

Requiem for a Dream

G. Games

Concentration - a game for practicing topic-related vocabulary

Bingo - a game for practicing topic-related vocabulary

Recycling bingo

Trivia

H. Songs

Anny's Song - a song to practice vowel sounds 


\section{Appendix B}

Sample Situations and Questions for the Oral Exams

\section{Student A}

You have heard that cars in Costa Rica are a major source of pollution. Ask your partner for possible solutions.

Student B:

Your partner is worried about the pollution caused by cars in Costa Rica. Talk about how driving habits and car maintenance can either add to the problem or help to solve it.

\section{Student A}

You are a customer in a cafeteria who suffers from asthma. You are telling a cafeteria manager that he/she should provide smoking and nonsmoking areas. Tell him/her about the risks of secondhand smoke.

\section{Student B}

You are a cafeteria manager who is a heavy smoker. You allow people to smoke in the cafeteria. You think smokers have the right of smoking wherever they want. Explain your point of view and mention the smoker's rights.

How do recycling and reusing save space, energy and natural resources? Explain.

What are two major water pollutants? What are their sources and effects? Explain.

How is addiction defined? What are some of the common symptoms of addictions? Can they be inherited or cured? What are the causes of addictions? What is the difference between drug addiction and drug abuse? What are some of the effects of substance abuse at the personal, family and social levels? 